\author{
www.cya.unam.mx/index.php/cya \\ Contaduría y Administración 63 (2), Especial 2018, 1-23

\title{
The importance to financial information in the decision-making process in company's family structure
}

\author{
La importancia de la información financiera para el proceso de toma de \\ decisiones en empresas de estructura familiar
}

\author{
Joana Patrícia Friães dos Santos, Amélia Maria Martins Pires \\ and Paula Odete Fernandes*
}

Polytechnic Institute of Bragança; Applied Management Research Unit (UNIAG),Portugal

Received 7 October 2017; accepted 10 May 2018

Available online 29 May 2018

\begin{abstract}
In Portugal most enterprises have a family pattern and an important role. Its importance is recognized and justifies the option to develop this research, which aims to determine whether these enterprises assign importance to financial information in the decision-making process. The work allowed gathering enough evidence to conclude on the importance of financial statements for the decision-making process, in particular as regards the use of the balance sheet and income statement. It was also concluded that financial information is primarily used to assess the financial impact, support the current management, investment decisions and comply with tax obligations.
\end{abstract}

JEL Classification: M14; M19; M41

Keywords: Accruals; Family business; Financial reporting; Decision-making.

\section{Resumen}

En Portugal, la mayoría de las empresas están orientadas a la familia, o que les hace tener un papel importante. La importancia de reconocerlo constituye suficiente motivación para desarrollar este trabajo, que tiene como objetivo determinar si estas empresas dan importancia a la información financiera en el proceso

\footnotetext{
*Corresponding author.

E-mail address: pof@ipb.pt (P. O. Fernandes)

Peer Review under the responsibility of Universidad Nacional Autónoma de México.
} 
de toma de decisiones. El trabajo permitió recoger suficiente evidencia para concluir sobre la importancia de los estados financieros para el proceso de toma de decisiones, en particular en lo que concierne a la utilización del balance y cuenta de resultados. También se concluyó que la información financiera se usa principalmente para evaluar el impacto financiero, apoyar la gestión actual, las decisiones de inversión y cumplir con las obligaciones tributarias.

Código JEL: JEL: M10; M41; M42

Palabras clave: Negocio familiar; Informes financieros; Toma de decisiones.

\section{Introduction}

Although there are few studies about companies' family (CF) (Bird et al., 2002; Bottino Antonaccio, 2007; Correia, 2003; Gomes, 2005; Silva et al., 1999) these studies began in 1950 (Andrade et al., 2013). However, it was in the sixties and seventies of the twentieth century that there has been an accentuation of studies about the CF (Andrade et al., 2013; Centurion \& Viana, 2007; Paulo, 2009; Sena et al., 2013), although some areas they are still little studied, such as the level of importance given to financial information (Shields, 2010; Carraher \& Auken, 2013) and not conclusive enough (Milanês, Lazano, Quirós, \& Calderón, 2010).

These companies (CF) appear still very associated with small business survival of a family without the intention or possibility of growth (Gallo \& Ribeiro, 1996; Paul, 2009) or to companies with problems and internal conflicts that could end in an unexpected way because of unprofessional management (Companies Family, 2015) and tend to emerge from the need that people have to have greater professional and personal independence, have more control over their own lives, or even by people who for various reasons were taken to create their own business (Borges et al, 2013; Silva et al., 1999). It is therefore often confused with small businesses. However, some are large CF (Coelho, 2002; Gallo \& Ribeiro, 1996; Paul, 2009; Ussman, 2004), and it is wrong to differentiate them according to their size (BottinoAntonaccio, 2007; Garbeti et al., 2008; Gomes, 2005; Walnut \& Machado, 2005; Silva et al., 1999).

In Portugal it is estimated that over $70 \%$ of the companies are family-oriented (Fernandes \& Ussman, 2012; Villax, s.d.), although this dominance is found in the national and international economy (Correia, 2003; Gallo \& Ribeiro, 1996; Garbeti et al., 2008; Gomes, 2005; Son et al., 2010; Nascimento et al., 2005; Neves, 2001; Nogueira \& Machado, 2005; Pamplona et al., 2015; Petry \& Nascimento, 2009; Silva et al., 1999). The current Portuguese business structure is formed mainly of small and medium-sized enterprises (SMEs) (INE, 2014; INE, 2015) although being mostly CF (Fernandes \& Ussman, 2012; Villax, s.d.). Like this, a bit similar what is happening around the world, the most of the CF existing in Portugal are small enterprises (Paul, 2009).

In Portugal, and Europe in general, most enterprises have a family pattern and an important role by for your great economic and social significance, although studies about several subject, such as the degree of utility her recognize the financial information, wasn't yet sufficiently developed. One of the main purposes that companies' annual reports should accomplish is to provide useful information for managers to make managements decisions. But in this respect the evidence available doesn't seem to be conclusive. In Spain or in Italy, the annual reporting 
doesn't help the managers to make management decisions because the own managers fomenting its interpretations about accounting matters and improving his accounting conception at the information's needs (Milanês et al., 2010).

Concerning the role of the financial information, there is a more or less general consensus that's importance for the continuity and survival of any company (Dantas, 2013). The accounting is an important management tool (Oliveira, 1997) and a means of support or help in the decision making process (Alves, 2005). However, are still few studies available on this subject, not only in Portugal (Correia, 2003; Shields, 2010; Carraher \& Auken, 2013) and/or inconclusive (Milanês et al., 2010). This issue is still undeveloped, not if sufficiently knowing which is the importance attributed by such companies to the financial information. The majority of the studies that have study the importance of the financial information was focused on the companies of a general form (e.g., Lima, 2000; Passos, 2010), on companies of a certain activity sector (e.g., Alves, 2005), or on companies of a certain size and/or location (e.g., Abatti, 2004; Bezerra, 2012; Laureano, 2006; Nunes \& Serrasqueiro, 2004; Santos, 2012; Stroeher \& Freitas, 2008). In this case, the preponderance of these enterprises in the national economy and the lack of results on the importance that they assigned to the financial information are the basis of this study, that aims determine the role and importance that accounting assumes in the decision-making process in these companies. To respond this objective this work is developed, in addition to this introduction and respective conclusions, on two major components. The first one, the theoretical framework, which aims to provide a general characterization of these companies in order to better understand its characteristics and its role and relevance in the national context and discuss the importance of financial information and its outputs in a business context. The second component, which concerns the empirical research work itself, comprising the explanation of the objectives and research hypotheses, the characterization of the sample, the information collection instrument and the statistical techniques for treatment and the analysis and discussion of the results and able us to provide answers to the general objective of the study, that is, discuss the importance and the role of financial information in the decision-making process of the Portuguese CF.

\section{Theoretical framework}

\section{The characteristics of the $C F$ and its relevance in the national context}

Be deemed to exist different criteria to try to define CF. Some seek to define them in opposition to unfamiliar companies (UFC) (Gomes, 2005; Paulo, 2009; Ussman, 2004), others based on succession management for future generations or based on property maintenance in family at least two generations (Nascimento et al., 2005; Bottino-Antonaccio, 2007; Brêtas et al., 2011). However, it is the property and the control the criteria most used to define CF (Ussman, 2004).

As there are numerous criteria to define CF was assumed for this study the definition presented by the Portuguese Family Business Association (APEF), which considers these companies as where the control is held by the family and where some of their members also take part and work (APEF, 2015). In fact, the CF have different own characteristics, that differentiate them from the other companies (Bottino-Antonaccio, 2007; Brêtas et al., 2011; Correia, 2003; Silva et al., 1999; Ussman, 2004), such as the existence of strong trust between the company and workers (Andrade et al., 2013; Borba et al., 2006; Bottino-Antonaccio, 2007), 
strong affective ties (Borba et al., 2006), family influence (Borba et al., 2006), great family loyalty (Andrade et al., 2013; Borba et al., 2006; Bottino-Antonaccio, 2007; Ussman, 2004), high conflict (Bottino-Antonaccio, 2007; Matos et al., 2007; Paulo, 2009; Ussman, 2004), share capital closed to members outsider the family (Matos et al., 2007; Paulo, 2009; Ussman, 2004), family involvement in the ownership and/or management (Leone, 1992), succession hooked to the hereditary factor (Leone, 1992), identification of family values with those of the organization (Garbeti et al., 2008; Leone, 1992; Paulo, 2009; Ussman, 2004), operating a long term perspective (Bottino-Antonaccio, 2007; Matos et al., 2007; Paulo, 2009; Ussman, 2004), difficulty in implementing professional management (Matos et al., 2007), relationship between the company and its founder (Matos et al., 2007; Paulo, 2009; Ussman, 2004), creation of values and family traditions (Matos et al., 2007; Paulo, 2009; Ussman, 2004), succession management (Garbeti et al., 2008), coincidence of interest between owners and management (Matos et al., 2007), possibility of having lower costs (Andrade et al., 2013; Matos et al., 2007), ease of communication within the organization (Matos et al., 2007), mutual respect (Andrade et al., 2013), family reputation (Matos et al., 2007), difficulty in separating the emotional from the rational (Borba et al., 2006), greater dedication (Borba et al., 2006), founded by a family member (Leone, 1992), traditional structure (Garbeti et al., 2007), although regarding as companies constantly evolving (Paulo, 2009; Ussman, 2004).

In relation to its weight and influence there are several studies that indicate a high prevalence of CF worldwide (Borges et al., 2013; Brêtas et al., 2011; Centurion \& Viana, 2007; Correia, 2003; Filho et al., 2010; Gallo \& Ribeiro, 1996; Garbeti et al., 2008; Gomes, 2005; Nascimento et al., 2005; Nogueira \& Machado, 2005; Pamplona et al., 2015; Petry \& Nascimento, 2009; Silva et al., 1999; Ussman, 2004) and the impact these have on individual economies in terms of creation and/or wealth distribution, namely through productivity and job creation (Andrade et al., 2013; Borges et al., 2013; Brêtas et al., 2011; Centurion \& Viana, 2007; Correia, 2003; Filho et al., 2010; Gallo \& Ribeiro, 1996; Garbeti et al., 2008; Gomes, 2005; Lethbridge, 1997; Nascimento et al., 2005; Nogueira \& Machado, 2005; Pamplona et al., 2015; Petry \& Nascimento, 2009; Silva et al., 1999).

There is not yet a clear idea about the importance of CF in the economy of each country (Correia, 2003). In Portugal, for example, is not known in depth which is their representativeness (Gallo \& Ribeiro, 1996; Ussman, 2004; Bottino-Antonaccio, 2007; Empresas \& Negócios, 2014; Paulo, 2009; Villax, s.d.) because the studies that exist are few and not enough conclusive (Bottino-Antonaccio, 2007; Paulo, 2009). According to Fernandes and Ussman (2012), Empresas and Negócios (2014) or and APEF (2015), the CF represent $70 \%$ of the total companies existing in Portugal and are responsible for $60 \%$ of employment and $50 \%$ of national wealth (APEF, 2015), which make them one of the main economic players (Correia, 2003; Nascimento et al., 2005; Ussman, 2004). They are mostly micro and small and medium-sized enterprises (Bottino-Antonaccio, 2007; Correia, 2003; Paulo, 2009). Indeed, the Portuguese environmental enterprises structure is generally composed by micro, small and mediumsized enterprises (INE, 2014; INE, 2015). However, the CF aren't associated with a specific dimension (APEF, 2015; Bottino-Antonaccio, 2007) or economic activity (Lethbridge, 1997; Ussman, 2004), insofar as there are CF in almost all activities sectors and dimensions (Correia, 2003; Leal, 2011; Ussman, 2004).

In other hand, the founding families of companies in Portugal represent a special class of large shareholders, who potentially have a strong and powerful voice in the management that 
accumulate with the property, as majority shareholders if not single shareholder's. In addition, to the non-diversified nature of their holdings (concentered capital in the family) the founders cultivate the long-term family presence, which makes their reputation and effects dependent on others. Such as banks, often developed a personal and well-informed relationship with companies' executives, suggesting that the presence of the family allows these relationships to be built over successive generations (Anderson, Mansi, \& Reeb, 2002).

The financial information as a result of the characteristics of the surrounding: analysis and discussion of their importance in the decision making in the $C F$

The environmental (cultural factors) are important to explaining and helping to understand the behavior observed in each country. Portugal is a developed country but in the European Union (EU) it's a small and peripheral economy, that justify some of its characteristics, in particular the small size of the capital market, the financing structure and the governance. It's a continental European country with a universal bank system (bank-oriented financing) and the Corporate Governance structure is very different from the USA but similar to most countries, like this France, Italy, Spain or Netherlands (Allen \& Gale, 2000). Is should be noted that "cod law accounting" as oriented toward legal compliance, with law disclosure and an alignment between financial and tax accounting. Banks or governments dominate as a source of finance and financial reporting is aimed at creditor protection (Melk \& Thomas, 2004).

Regarding corporate ownership concentration, the family control is more important in Continental Europe than UK or Ireland, and in the Continental Europe Portugal, together with Germany or France, shows the highest percentages of family control (Faccio \& Lang, 2002). In Portugal the family businesses have a very significant weight, which has immediate consequences for their growth possibilities (capital closed) and ownership and management tend to be concentrated, which hasn't only an impact on the governance structure but also on the importance and usefulness they tend to attribute to financial reporting. In this logic given that cultural factors are important to explaining and helping to understand the behavior observed, like in relation to the usefulness of financial information, Albuquerque, Quirós and Justino (2016) developed a study which led them to conclude that the managers and owners of small and medium enterprises in Portugal support their decisions between the level of conservatism and the secrecy of financial information. The high levels of conservatism and secrecy are certainly related to the type of information that is prepared and reported, and thus to the level of utility that is recognized. Conservatism and secrecy are two of the main characteristics of the accounting systems of the continental matrix, where the Portuguese accounting system is included.

The accounting takes on a great importance in business management from the beginning of commercial activity (Santos, 2012). In a globalized and competitive world, the companies are increasingly exposed and pressured to adapt to constant changes (technological, economic, financial, among others) and are forced to restructure to remain competitive and in the market (Bottino-Antonaccio, 2007; Garbeti et al., 2008; Passos, 2010). At this particular, the accounting presents increasingly as a potent management instrument (Bezerra, 2012; Borges et al., 2010; Oliveira, 1997; Passos, 2010) able to help them to maximize their levels of efficiency and effectiveness (Bezerra, 2012), that is, it offers to help in the decision making process in companies by providing relevant and timely financial information (Bezerra, 2012; Passos, 2010). 
The accounting while information system comes to respond to diverse needs (all stakeholders). In that circumstance directs the information to satisfy very different needs (Pires \& Rodrigues, 2011) arising from the environment which also conditioned (Pires \& Rodrigues, 2011; Pires et al., 2015). The development and the assumptions when was based the accounting system begin influenced from factors such as the legal system, larger or smaller interference of taxation, the characteristics of the business fabric, the main ways to financing, capital structure or separation between ownership and management (Tua, 1998). So that, the financial information isn't only result of the accounting system of each country but also the surrounding conditioners. The financial information doesn't assume the same importance to all stakeholders and hasn't equal importance to all companies because they don't have all same needs. For example, they depend on the size of the capital structure, the level of debt, the complexity of the operations or the level of risk they assume. By that, there are characteristics that explain the level information disclosure although not all confirm the existence of a positive association (Ferreira, 2008). In this context have been made many studies that show the influence of the sources of financing used or the characteristics of the business environment. The CF tend to satisfy their financing needs by the family or to bank credit (Alves \& Mendonça, 2013), given that the CF are not very likely to let in outsiders (Alves \& Mendonça, 2013). Fact that in certain circumstances tends to hinder the access to credit, particularly when it comes to large amounts of capital (Alves \& Mendonça, 2013; Lethbridge, 1997; Santos, 2014).

In other hand, the relationship between taxation and accounting to some extent justified the differences existing in the information that is prepared by the companies (Pires \& Rodrigues, 2011; Pires et al., 2015; Radebaugh \& Gray, 1993; Rodrigues et al., 2014). In Portugal, for example, there is some interference of taxation in accounting, much due to the fact that the tax rule to have anticipated the accounting standard and have occupied the place where would be the accounting (Rodrigues et al., 2014). In general, the companies tend to adopt accounting solutions that will enable them to maximize the taxation benefits but also those that are accepted by the tax rule (Dechow et al., 1995; Scholes et al., 1990).

The separation of ownership and management of companies is another factor that tends to affect the quality of information. The management has its own reasons, so that in cases where ownership and management are separated it can be produced agency costs (Watts \& Zimmermann, 1978). However, this question doesn't tend to put in CF (Matos et al., 2007), where normally the ownership and management are concentrated (Almeida, 2010; Brêtas et al., 2011; Freitas \& Barth, 2011; Nascimento et al., 2005; Nascimento et al., 2006). Moreover, in companies where ownership and management are concentrated, the decision making process is not always done in a professional way, particularly when it comes to small businesses, where decision make themselves based on improvisation and intuition (Bezerra, 2012) and not so much away the financial information which is prepared and disclosed (Pires \& Rodrigues, 2011; Rodrigues et al., 2014). This could be associated with the fact that the administrators/ managers of these companies have little knowledge of accounting and about the benefits that the outputs of accounting can pose to the management of their organizations (Laureano, 2006; Santos, 2014). In this circumstance, they do not recognize its importance and do not use it in the decision making processs (Stroeher \& Freitas, 2008). It is based on intuition (Bezerra, 2012; Pires \& Rodrigues, 2011; Pires et al., 2015; Rodrigues et al., 2014) and professional experience (Bezerra, 2012) to manage and conduct the company. In these cases, they tend to use the financial information only for the purpose of complying with the tax obligations 
(Laureano, 2006; Pires \& Rodrigues, 2011; Pires et al., 2015; Rodrigues et al., 2014). And last but not least, the amount of financial information to be prepared and disclosed by companies derives from the balance between the cost of their preparation and the return that it could provide. In this circumstance, the companies tend to prepare the financial information to which they are required by law and that they can take some benefit, always bearing in mind the need to reduce costs to gain competitiveness (Santos, 2013).

\section{Research methodology}

\section{Study objective and research hypotheses}

There are few published studies that examine the use of financial information by small firms (Carraher \& Auken, 2013) as well as the level of understanding that owners have about their content and importance, particularly in small businesses (Sian \& Roberts, 2009). In turn, it is also known that companies that prepare this information internally, instead of externally, gain more knowledge about their content, which may make them more comfortable and more prone to use (Smallbone, North \& Leigh, 1993). The external preparation of the financial statements can signal the financial capacity, sophistication and internal expertise of the company (Breen, Sciulli \& Calvert, 2004). The frequency with which the information is prepared can be a good indicator of the use and importance assigned to it. Companies that prepare information less often are less sophisticated and have lower needs (McMahon \& Stanger, 1995; Cassar, 2009). The capital that the company has influences the decision-making process, fundamentally in smaller companies, since it determines the level of available resources (Neeley \& Auken, 2010). The decision process is also influence by the educational levels of the owners. The higher the probability of a greater understanding of informational content (Hanlon \& Saunders, 2007; Neeley \& Auken, 2010), in addition to the owners gain the experience and education necessary to run the company as their revenues grow and the investment increases (Neeley \& Auken, 2010). Based on these thoughts and considering that the study was developed with the objective of studying the importance of financial information in the decision making process in the Portuguese $\mathrm{CF}$, were established the following research hypotheses $(\mathrm{RH})$ :

$\mathrm{RH}_{1}$ : There is an association between the importance given to financial information and the place where it is prepared.

$\mathrm{RH}_{2}$ : There is an association between the importance given to financial information and the cost that the Portuguese $\mathrm{CF}$ have with their preparation.

$\mathrm{RH}_{3}$ : There is an association between the knowledge of the managers about financial information prepared by the company and its respective use in the decision making process.

$\mathrm{RH}_{4}$ : There is a relationship between the use of financial information and capital structure of the company.

$\mathrm{RH}_{5}$ : There is a relationship between financial autonomy and the importance given to financial information.

$\mathrm{RH}_{6}$ : There is an association between academic education of managers or members of the board and the importance given to financial information.

Sample data collection instrument and data processing techniques

The population corresponds to the CF associated the APEF and registered at Portugal. 
Should be noted however that this group of companies is not representative of the overall population of Portuguese CF. For a total of 279 companies belonging to the APEF, 7 are not registered in Portugal, and so the population to be considered for this study is 272 companies. Of these, only it was possible to establish contact, by telephone and e-mail, from March 19 to June 15, 2015, with 245 companies. Were applied 245 questionnaires but only 66 responses were obtained which corresponds to a response rate of $26.94 \%$. The sample is composed of 66 Portuguese $\mathrm{CF}$, not representative of the population. In this regards, this study has an exploratory character, able to arrive at favorable estimates of population characteristics but do not allow to generalize to the population.

The questionnaire consists of three parts. The first to collect sample information in order to be able to develop their characterization, a second to identify the type of capital structure, ownership and management, and a third which responds to specific objectives and test RH. The questionnaire was validated in order to verify that the questions were constructed in an understandable and clear way, by performing a pretest. It should be noted that the questions were measured on a Likert scale of 5 points, where 1 was the least favorable and 5 was the most favorable; and there were also some multiple-choice questions. For convenience the 12 $\mathrm{CF}$ who applied the questionnaire for validation are not associated with the APEF. The results obtained in the pretest led to the alteration of 8 questions before proceeding to its application to members of the APEF.

In order to respond to specific objectives and research hypotheses were used statistical techniques of exploratory descriptive analysis, including absolute and relative frequency, mean and standard deviation, and statistical tests for inferential analysis, namely non-parametric tests. The implicit variables in the questionnaire are mostly measured in nominal scale so their evaluation can only be made using non-parametric tests (Hill \& Hill, 2002).

That in order to make the inferential analysis, in which the variables are measured in nominal scale, was applied the Fischer test and the Phi correlation coefficient test in order to analyse the existence of association and the intensity of the association between the study variables. However, in order to implement the Fisher test has been necessary produce a $2 \times 2$ table so will be taken into consideration as cutting as the median. In this sense, to be able to apply these tests was to convert some of the variables into dichotomy variables, namely the academic education of administrators/managers, the sources used in the preparation of financial information, the evaluation of the knowledge of the administrators/managers about the financial information that is prepared by the company and the importance allocated to the financial statements. It was also necessary to use the Spearman correlation coefficient to examine whether there is a relationship between qualitative variables measured on an ordinal scale.

Note that decisions on research hypotheses will be taken with reference to a $5 \%$ significance level. When there is more than one hypothesis research to support the hypothesis main research will be used as criteria partial validation main hypothesis if at least one of the support confirm hypotheses.

\section{Analysis and discussion of results}

\section{Importance degree of assigned to the financial information and its finality}

Considering that the financial statements affect all stakeholders and although there are some examples of studies of how small and medium-sized firms use financial statements in decision-making, most of the available research focused only on large firms (Shields, 2010). 
Carraher and Auken (2013) developed a study with the objective of knowing this subject and conclude there is very little works on the role of the financial statements in decision making in the small or medium companies. The known results show that the owners aren't prepared to interpret the contents of FS so don't use them when making decision (Halabi, Barret, \& Dyt, 2010) or they don't feel truly capable of interpreting theme (Carraher \& Auken, 2013). In this circumstance, and considering that the financial statements have as main objective to provide useful information about the performance, financial position and changes in the financial position of a certain company (Almeida, 2012; Silva, 2010) to support and/or assist in the decision-making process of a large number of stakeholders (Almeida, 2012; Bezerra, 2012; Fonseca, 2014; Silva, 2010), the degree of importance recognized to each of the elements that are part of the financial statements was analysed.

The results (Table 1) show that administrators/managers give extreme importance to the balance sheet and the income statement (69.23\% and $78.46 \%$ respectively), which is in line with our expectations because it comes to financial statements and disclosure mandatory preparation by any company. The recognized importance to the statement of changes in equity, statement of cash flows and disclosures, although not so significant and concentrated, is also positive (about $20.97 \%, 30.16 \%$ and $38.60 \%$ of respondents attribute extreme importance, $33.87 \%, 33.33 \%$ and $28.07 \%$ much importance, and $30.65 \%, 26.98 \%$ and $24.56 \%$ moderate importance, respectively). We conclude, therefore, that the administrators/managers recognize great importance to the statements financial, which is most evident in relation to the balance sheet and the income statement, in line with the conclusions presented by Santos (2014) and Albuquerque et al. (2013), they also concluded that direction. This way, and on average, respondents recognize greater importance to the balance sheet, income statement and disclosure, which allows the hierarchy about the importance that each user (stakeholders) recognizes each of the pieces that make up the set of the financial statements with the balance sheet and income statement to occupy the top spots. Overall, it was found that most administrators/managers recognize the importance of financial information, classifying it as much and extremely important, as had already been completed by Lopes (2014).

Table 1

Importance degree assigned to each part that forms the basic set of financial statements.

\begin{tabular}{|c|c|c|c|c|c|c|c|c|}
\hline & $\begin{array}{c}\text { Nothing } \\
\text { important }\end{array}$ & $\begin{array}{c}\text { Little } \\
\text { important }\end{array}$ & $\begin{array}{c}\text { Moderately } \\
\text { important }\end{array}$ & $\begin{array}{c}\text { Very } \\
\text { important }\end{array}$ & $\begin{array}{l}\text { Extremely } \\
\text { important }\end{array}$ & $\begin{array}{c}\text { No } \\
\text { opinion }\end{array}$ & Mean & $\begin{array}{l}\text { Standard } \\
\text { Deviation }\end{array}$ \\
\hline $\begin{array}{l}\text { Balance sheet } \\
(n=65)\end{array}$ & - & - & $\begin{array}{c}4 \\
6.15 \%\end{array}$ & $\begin{array}{c}16 \\
24.62 \%\end{array}$ & $\begin{array}{c}45 \\
69.23 \%\end{array}$ & - & 4.63 & 0.601 \\
\hline $\begin{array}{l}\text { Income statement } \\
(\mathrm{n}=65)\end{array}$ & - & - & $\begin{array}{c}1 \\
1.54 \%\end{array}$ & $\begin{array}{c}13 \\
20 \%\end{array}$ & $\begin{array}{c}51 \\
78.46 \%\end{array}$ & - & 4.77 & 0.46 \\
\hline $\begin{array}{l}\text { Statement of } \\
\text { changes in equity }\end{array}$ & $\begin{array}{c}3 \\
4.84 \%\end{array}$ & $\begin{array}{c}6 \\
9.68 \%\end{array}$ & $\begin{array}{c}19 \\
30.65 \%\end{array}$ & $\begin{array}{c}21 \\
33.87 \%\end{array}$ & $\begin{array}{c}13 \\
20.97 \%\end{array}$ & - & 3.56 & 1.081 \\
\hline $\begin{array}{l}\text { Statement of cash } \\
\text { flows }(n=63)\end{array}$ & $\begin{array}{c}2 \\
3.17 \%\end{array}$ & $\begin{array}{c}4 \\
6.35 \%\end{array}$ & $\begin{array}{c}17 \\
26.98 \%\end{array}$ & $\begin{array}{c}21 \\
33.33 \%\end{array}$ & $\begin{array}{c}19 \\
30.16 \%\end{array}$ & - & 3.81 & 1.045 \\
\hline $\begin{array}{l}\text { Disclosure } \\
(\mathrm{n}=57)\end{array}$ & - & $\begin{array}{c}2 \\
3.51 \%\end{array}$ & $\begin{array}{c}14 \\
24.56 \%\end{array}$ & $\begin{array}{c}16 \\
28.07 \%\end{array}$ & $\begin{array}{c}22 \\
38.60 \%\end{array}$ & $\begin{array}{c}3 \\
5.26 \%\end{array}$ & 4.07 & 0.908 \\
\hline
\end{tabular}


As regards the use of financial information and purpose it turns (Table 2), except for day to day operations, most CF tend, on average, to use the financial information often for evaluating the financial impact (4.03 points), comply with tax obligations (4.30 points), making the current management (4.13 points) and take investment decisions (4.06 points). It is used sometimes to measure performance (3.98 points), to follow up goals (3.95 points), comply with the demands of financial creditors (3.64 points), and perform routine operations (3.47 points) and to take funding decisions (3.94 points). However, the results obtained on the use of financial information to measure performance, to monitor the goals and evaluate the financial impacts are not in line with Santos (2014), who concluded that most administrators/managers do not use the financial information for these purposes. The frequency with which financial information is used to perform routine operations (sometimes) take investment decisions (often) and financing decisions (sometimes), may be associated with the importance that administrators/managers recognize to it but also to characteristics of the $\mathrm{CF}$. In addition to being predominantly micro, small and medium-sized enterprises (INE, 2014; INE, 2015; Pires \& Rodrigues, 2011; Ussman, 2004), are closed off because they are family kind (Borges et al., 2013; Brêtas et al., 2011; Centurion \& Viana, 2007; Correia, 2003; Filho et al., 2010; Gallo \& Ribeiro, 1996; Garbeti et al., 2008; Gomes, 2005; Nascimento et al., 2005; Nogueira \& Machado, 2005; Pamplona et al., 2015; Petry \& Nascimento, 2009; Silva et al., 1999), with capital and concentrated management and work on a long-term perspective. These circumstances help to explain the fact that funding decisions are not strongly supported in financial information and therefore not be given more importance, as had also concluded Santos (2014), these businessmen attribute to the investment decisions and day to day operations much importance and funding decisions of moderate importance. These results, show that the financial information is first used to comply with tax obligations and then to questions related to the management, which is in line with the results presented by Bezerra (2012), Santos (2014), Kassai (1997) cited by Silva (2010) and Stroeher and Freitas (2008), which concluded that companies have an increased concern to comply with tax obligations than with aspects related to the management.

Table 2

Use of financial information and the purpose for which it is used.

\begin{tabular}{|c|c|c|c|c|c|c|c|}
\hline & Never & Rarely & Sometimes & Oftentimes & Always & Mean & $\begin{array}{l}\text { Standard } \\
\text { Deviation }\end{array}$ \\
\hline $\begin{array}{l}\text { Measure performance } \\
(n=63)\end{array}$ & $\begin{array}{c}1 \\
1.59 \%\end{array}$ & $\begin{array}{c}2 \\
3.17 \%\end{array}$ & $\begin{array}{c}16 \\
25.40 \%\end{array}$ & $\begin{array}{c}22 \\
34.92 \%\end{array}$ & $\begin{array}{c}22 \\
34.92 \%\end{array}$ & 3.98 & 0.942 \\
\hline $\begin{array}{l}\text { Follow up targets } \\
\text { (objectives) }(n=63)\end{array}$ & $\begin{array}{c}1 \\
1.59 \%\end{array}$ & $\begin{array}{c}5 \\
7.94 \%\end{array}$ & $\begin{array}{c}12 \\
19.05 \%\end{array}$ & $\begin{array}{c}23 \\
36.51 \%\end{array}$ & $\begin{array}{c}22 \\
34.92 \%\end{array}$ & 3.95 & 1.007 \\
\hline $\begin{array}{l}\text { Assess financial impacts } \\
(n=61)\end{array}$ & - & - & $\begin{array}{c}19 \\
31.15 \%\end{array}$ & $\begin{array}{c}21 \\
34.43 \%\end{array}$ & $\begin{array}{c}21 \\
34.43 \%\end{array}$ & 4.03 & 0.816 \\
\hline Tax obligations $(n=63)$ & - & $\begin{array}{c}1 \\
1.59 \% \\
\end{array}$ & $\begin{array}{c}10 \\
15.87 \% \\
\end{array}$ & $\begin{array}{c}21 \\
33.33 \% \\
\end{array}$ & $\begin{array}{c}31 \\
49.21 \% \\
\end{array}$ & 4.3 & 0.796 \\
\hline $\begin{array}{l}\text { Requirements of financial } \\
\text { creditors }(n=61)\end{array}$ & $\begin{array}{c}3 \\
4.92 \%\end{array}$ & $\begin{array}{c}6 \\
9.84 \%\end{array}$ & $\begin{array}{c}16 \\
26.23 \%\end{array}$ & $\begin{array}{c}21 \\
34.43 \%\end{array}$ & $\begin{array}{c}15 \\
24.59 \%\end{array}$ & 3.64 & 1.111 \\
\hline $\begin{array}{l}\text { Current management } \\
(\mathrm{n}=62)\end{array}$ & - & $\begin{array}{c}2 \\
3.23 \%\end{array}$ & $\begin{array}{c}11 \\
17.74 \%\end{array}$ & $\begin{array}{c}26 \\
41.94 \%\end{array}$ & $\begin{array}{c}23 \\
37.10 \%\end{array}$ & 4.13 & 0.82 \\
\hline
\end{tabular}



http://dx.doi.org/10.22201/fca.24488410e.2018.1727

\begin{tabular}{lccccccc} 
& Never & Rarely & Sometimes & Oftentimes & Always & Mean & $\begin{array}{l}\text { Standard } \\
\text { Deviation }\end{array}$ \\
\hline $\begin{array}{l}\text { Day to day operations } \\
(\mathrm{n}=62)\end{array}$ & 2 & 9 & 23 & 14 & 14 & 3.47 & 1.097 \\
\hline $\begin{array}{l}\text { Investment decisions } \\
(\mathrm{n}=62)\end{array}$ & $3.23 \%$ & $14.52 \%$ & $37.10 \%$ & $22.58 \%$ & $22.58 \%$ & 3.47 \\
\hline $\begin{array}{l}\text { Funding decisions } \\
(\mathrm{n}=63)\end{array}$ & $1.61 \%$ & - & 18 & 18 & 25 & & \\
\hline
\end{tabular}

As is seen the financial information

The quality of the information is the most important precedent for the satisfaction of the different users and so are the same users who consider the availability and accuracy of the information made available as a key element. In the same way, they also claim that good use of information supports companies in their decisions and leads them to better results at the organizational level (Almazán, Tovar, \& Quintero (2017).

The results show (Table 3) that CF tend to view financial information prepared as a legal obligation and a need for management, especially this latter $(75.76 \%)$, which seems to mean that companies tend to prepare financial information to support the decision-making process and not just for comply with legal and fiscal obligations. These results aren't in line with those obtained by Bezerra (2012), who concluded that companies are more concerned to comply with the law than with the aspects related to the management, nor with Santos (2014), who found that the financial information is primarily used to comply with tax obligations and then to assist the decision making process.

Although not entirely in the same sense, these results help to understand the conclusions of Garcia-Perz-de-Lema and Durendéz (2006), who concluded that managers of family firm's use a little bit managements tools, little financial information and a cash budget for the decision making process. This is closely related for their characteristics because this companies wasn't mentalized to valorize this tools. For authors, the ownership and control in the family and the influence of the family in the management decisions could be the reason they have different management behavior to those of non-family firms. For other hand, the homeowners aren't prepared to interpret the contents of financial statements and therefore do not use them when making decisions (Halabi et al., 2010; Hanlon \& Saunders, 2007; Neeley \& Auken, 2010) or do not feel truly able to interpret their content (Carraher \& Auken, 2013).

Table 3

Use of financial information and the purpose for which it is used.

\begin{tabular}{lcc}
\hline & $\mathbf{n}$ & $\%$ \\
\hline A legal imperative & 2 & $3.03 \%$ \\
A need for management & 2 & $3.03 \%$ \\
Both, but as fundamentally a legal imperative & 12 & $18.18 \%$ \\
Both, but as fundamentally a need for management & 50 & $75.76 \%$ \\
\hline Total & 66 & $100 \%$ \\
\hline
\end{tabular}




\section{Opinion owners, managers or members of the board about the financial information}

The results (Table 4) show that the owners, managers or members of the board tend to view financial information as a necessity to meet the tax requirements and to support the decision making process $(81.82 \%)$. These results are in line with those presented by Laureano (2006), for whom most of the managers see the financial information as a necessary tool to answer to tax requirements and support the decision making process, but differ from those presented by Santos (2014), who states that the financial information is mostly used by companies to meet their management needs.

Table 4

Opinion owners, managers or members of the board about the financial information.

\begin{tabular}{lcc}
\hline & $\mathbf{n}$ & $\boldsymbol{\%}$ \\
\hline A necessary tool to meet the tax requirements & 3 & $4.55 \%$ \\
A necessary tool to support the decision making process & 8 & $12.12 \%$ \\
Both of the above & 54 & $81.82 \%$ \\
The result of a legal imperative & 1 & $1.52 \%$ \\
\hline Total & 66 & $100 \%$ \\
\hline
\end{tabular}

\section{Elaborated financial information and its influence in the activity sector}

The acquired companies can in theory use different normative references (IAS/IFRS, NCRF, NCRF-PE and NCRF-ME). In this circumstance, those who apply the IAS/IFRS or NCRF are required to prepare more financial statements that applying the NCRF-ME or NCRF-PE, they should only prepare the balance sheet, the income statement and disclosures (Almeida, 2012; Diário da República, 2009; Rodrigues, 2011). That is, the statement of changes in equity and statement of cash flows are optional character to those who apply the NCRF-ME or NCRF-PE (Almeida, 2012; Diário da República, 2009; Rodrigues, 2011). In this way the CF adopting IAS/IFRS or IFRS are required to prepare more financial information than those who adopt the NCRF-ME or the NCRF-PE, which is equivalent to say that these adopt the NCRF ME or the NCRF-PE can, if they wish, prepare and disclose financial information beyond what is legally required. In this sense, we tried to analyse what the financial information that is more prepared for $\mathrm{CF}$ and it varies depending on the sector of activity.

The results, as well as allow an inspection that most EF applies the NCRF (34 companies), also show that the financial statements are more prepared (Table 5). The most prepared financial statement is the balance (62 companies), followed by the income statement ( 59 companies) and disclosures (55 companies). The statement of changes in equity and statement of cash flows are prepared by 40 and 44 companies, respectively. These differences are, of course, due to the different regulatory frameworks adopted but not cease to be strange because the balance sheet, income statement and disclosures are common and therefore should provide equal representation. This leads us to conclude that the administrators/managers hold little knowledge about the different normative references and consequently on the financial information that the company is required to prepare because of the 65 companies that responded to this question any of the statutory financial statements (common to all normative references) got all the answers. However, it seems to be in the service sector of activity that this lack of knowledge by the administrators/managers becomes more apparent (Table 6). In this sense, these results are somewhat aligned with those presented by Laureano (2006), Santos (2014) and Stroeher and Freitas (2008), who also concluded the lack of accounting knowledge by entrepreneurs. 

http://dx.doi.org/10.22201/fca.24488410e.2018.1727

Table 5

Financial statements prepared depending on the accounting standard adopted.

\begin{tabular}{lccccc}
\hline $\begin{array}{c}\text { Accounting } \\
\text { standard }\end{array}$ & $\begin{array}{c}\text { Balance } \\
\text { sheet }\end{array}$ & $\begin{array}{c}\text { Income } \\
\text { statement }\end{array}$ & $\begin{array}{c}\text { Statement of } \\
\text { changes in equity }\end{array}$ & $\begin{array}{c}\text { Statement } \\
\text { of cash flows }\end{array}$ & Disclosures \\
\hline IAS/IFRS $(\mathrm{n}=9)$ & 9 & 9 & 6 & 7 & 8 \\
NCRF $(\mathrm{n}=34)$ & 33 & 31 & 27 & 29 & 31 \\
NCRF-PE $(\mathrm{n}=12)$ & 12 & 10 & 4 & 4 & 10 \\
NCRF-ME $(\mathrm{n}=10)$ & 8 & 9 & 3 & 4 & 6 \\
\hline Total & 62 & 59 & 40 & 44 & 55 \\
\hline
\end{tabular}

Regarding the amount of financial information produced by the $\mathrm{CF}$ and the business sector in which they operate, the results (Table 6) show that micro companies, that adopt NCRF-ME, produce more optional information that small businesses and that they are the micro and small and medium-sized enterprises in the sector of services that prepare more optional information, in particular the statement of changes in equity and the statement of cash flows. However, these results are not very significant so do not establish any relationship between the amount of financial information optional character prepared by the company and its industry.

Table 6

Financial statements prepared depending on the activity sector.

\begin{tabular}{|c|c|c|c|c|c|c|}
\hline $\begin{array}{c}\text { Accounting } \\
\text { standard }\end{array}$ & $\begin{array}{l}\text { Activity } \\
\text { sector }\end{array}$ & $\begin{array}{c}\text { Balance } \\
\text { sheet }\end{array}$ & $\begin{array}{c}\text { Income } \\
\text { statement }\end{array}$ & $\begin{array}{c}\text { Statement of } \\
\text { changes in equity }\end{array}$ & $\begin{array}{c}\text { Statement } \\
\text { of cash flows }\end{array}$ & Disclosures \\
\hline $\begin{array}{l}\text { IAS/IFRS } \\
(\mathrm{n}=9)\end{array}$ & $\begin{array}{l}\text { Industry and } \\
\text { building }(n=5) \\
\text { Trade }(n=2) \\
\text { Services }(n=2)\end{array}$ & $\begin{array}{l}5 \\
2 \\
2 \\
\end{array}$ & $\begin{array}{l}5 \\
2 \\
2 \\
\end{array}$ & $\begin{array}{l}4 \\
2 \\
0\end{array}$ & $\begin{array}{l}5 \\
2 \\
0\end{array}$ & $\begin{array}{l}5 \\
2 \\
1 \\
\end{array}$ \\
\hline Total & & 9 & 9 & 6 & 7 & 8 \\
\hline $\begin{array}{l}\text { NCRF } \\
(n=34)\end{array}$ & $\begin{array}{l}\text { Industry and } \\
\text { building }(n=6) \\
\text { Trade }(n=11) \\
\text { Services }(n=12) \\
\text { Other }(n=5)\end{array}$ & $\begin{array}{c}6 \\
10 \\
12 \\
5\end{array}$ & $\begin{array}{c}6 \\
10 \\
11 \\
5\end{array}$ & $\begin{array}{l}5 \\
9 \\
8 \\
5\end{array}$ & $\begin{array}{l}6 \\
9 \\
9 \\
5\end{array}$ & $\begin{array}{c}6 \\
9 \\
11 \\
5\end{array}$ \\
\hline Total & & 33 & 32 & 27 & 29 & 31 \\
\hline $\begin{array}{l}\text { NCRF-PE } \\
(n=12)\end{array}$ & $\begin{array}{l}\text { Industry and } \\
\text { building }(n=3) \\
\text { Trade }(n=1) \\
\text { Services }(n=6) \\
\text { Other }(n=2)\end{array}$ & $\begin{array}{l}3 \\
1 \\
6 \\
2\end{array}$ & $\begin{array}{l}3 \\
1 \\
4 \\
2 \\
\end{array}$ & $\begin{array}{l}1 \\
1 \\
2 \\
0\end{array}$ & $\begin{array}{l}2 \\
0 \\
1 \\
1\end{array}$ & $\begin{array}{l}3 \\
1 \\
4 \\
2 \\
\end{array}$ \\
\hline Total & & 12 & 10 & 4 & 4 & 10 \\
\hline $\begin{array}{l}\text { NCRF-ME } \\
(\mathrm{n}=10) \\
\text { Total }\end{array}$ & $\begin{array}{l}\text { Trade }(n=1) \\
\text { Services }(n=9)\end{array}$ & $\begin{array}{l}1 \\
7 \\
8\end{array}$ & $\begin{array}{l}1 \\
8 \\
9\end{array}$ & $\begin{array}{l}1 \\
3 \\
4\end{array}$ & $\begin{array}{l}1 \\
4 \\
5\end{array}$ & $\begin{array}{l}1 \\
6 \\
7\end{array}$ \\
\hline
\end{tabular}

Importance assigned to financial information depending on the size

In general, can be seen (Table 7), regardless of firm size, that there is a higher concentration of responses in higher degrees of importance (very and a lot important) when it comes to the balance sheet and income statement. The same is not true about the importance attributed to the statement of changes in equity, the statement of cash flows and disclosures, which is more 
dispersed by varying degrees of importance. However, were the micro and small companies that attributed no importance to the statement of changes in equity and statement of cash flows, which may be due to the fact that these companies are only compelled to prepare the balance sheet, income statement and disclosures (Almeida, 2012; Diário da República, 2009; Rodrigues, 2011). In this way, administrators/managers tend to attribute to the financial statements of compulsory preparation a greater degree of importance. By that, the importance of which is recognized to the financial information differs with the size of the company.

Table 7

Importance attributed to the financial statements depending on the size.

\begin{tabular}{|c|c|c|c|c|c|c|}
\hline $\begin{array}{c}\text { Size of } \\
\text { enterprise }\end{array}$ & $\begin{array}{c}\text { Degree of } \\
\text { importance assigned }\end{array}$ & $\begin{array}{c}\text { Balance } \\
\text { sheet }\end{array}$ & $\begin{array}{c}\text { Income } \\
\text { statement }\end{array}$ & $\begin{array}{c}\text { Statement of } \\
\text { changes in equity }\end{array}$ & $\begin{array}{c}\text { Statement } \\
\text { of cash flows }\end{array}$ & Disclosures \\
\hline \multirow{5}{*}{$\begin{array}{l}\text { Micro } \\
\text { enterprises } \\
(n=22)\end{array}$} & Nothing important & 0 & 0 & 2 & 2 & 0 \\
\hline & Little important & 0 & 0 & 0 & 1 & 0 \\
\hline & Moderately important & 1 & 0 & 5 & 4 & 4 \\
\hline & Very important & 5 & 5 & 10 & 8 & 4 \\
\hline & Extremely important & 16 & 17 & 3 & 6 & 6 \\
\hline \multirow[t]{2}{*}{ Total } & & 22 & 22 & 20 & 21 & 14 \\
\hline & Nothing important & 0 & 0 & 1 & 0 & 0 \\
\hline \multirow{4}{*}{$\begin{array}{l}\text { Small } \\
\text { enterprises } \\
(n=20)\end{array}$} & Little important & 0 & 0 & 3 & 1 & 2 \\
\hline & Moderately important & 3 & 1 & 8 & 6 & 5 \\
\hline & Very important & 3 & 2 & 3 & 5 & 4 \\
\hline & Extremely important & 14 & 17 & 4 & 7 & 8 \\
\hline \multirow{6}{*}{$\begin{array}{l}\text { Total } \\
\text { Medium } \\
\text {-sized } \\
\text { enterprises } \\
(n=15)\end{array}$} & & 20 & 20 & 19 & 19 & 19 \\
\hline & Nothing important & 0 & 0 & 0 & 0 & 0 \\
\hline & Little important & 0 & 0 & 2 & 1 & 0 \\
\hline & Moderately important & 0 & 0 & 4 & 5 & 4 \\
\hline & Very important & 3 & 2 & 4 & 5 & 7 \\
\hline & Extremely important & 11 & 12 & 4 & 3 & 3 \\
\hline \multirow{6}{*}{$\begin{array}{l}\text { Total } \\
\text { Large } \\
\text { enterprises } \\
(n=3)\end{array}$} & & 14 & 14 & 14 & 14 & 14 \\
\hline & Nothing important & 0 & 0 & 0 & 0 & 0 \\
\hline & Little important & 0 & 0 & 0 & 0 & 0 \\
\hline & Moderately important & 0 & 0 & 0 & 1 & 0 \\
\hline & Very important & 1 & 1 & 1 & 0 & 0 \\
\hline & Extremely important & 2 & 2 & 2 & 2 & 2 \\
\hline \multicolumn{2}{|l|}{ Total } & 3 & 3 & 3 & 3 & 2 \\
\hline
\end{tabular}

On the other hand, and given that cultural factors, as we have already had occasion to mention, are important to explain and help understand the behavior observed in each country, the results presented by Albuquerque et al. (2016), which shows the managers and owners of small and medium-sized enterprises in Portugal support their decisions between the level of conservatism and the secrecy of financial information, may help to clarify this issue. This is, considering that conservatism and secrecy are two of the main characteristics of the accounting systems of the continental matrix, which include the Portuguese accounting system, the high levels of conservatism and secrecy are certainly related with the level of utility that is recognized for financial information and that this relative importance varies with the size of the company.

Proof of research hypotheses

Considering the nature of the variables involved were appealed to the Fisher test to proceed 
with the validation of " $\mathrm{RH}_{1}$ : There is an association between the importance given to financial information and the place where it is prepared". The results (Table 8) show no sufficient statistical evidence to state that the importance given to financial information and the site where it is prepared (inside the company or outside the company) are associated, because the p-value is higher than the level of significance of $5 \%$. Thus, it is not possible to corroborate $\mathrm{RH}_{1}$.

Table 8

Fisher test on $\mathrm{RH}_{1}$.

\begin{tabular}{|c|c|c|}
\hline Research hypotheses & Variables & p-value \\
\hline \multirow{5}{*}{$\begin{array}{l}\mathbf{R H}_{\mathbf{1}} \text { : There is an association between the } \\
\text { importance given to financial information } \\
\text { and the place where it is prepared. }\end{array}$} & $\begin{array}{c}\text { Balance sheet } x \text { Place where financial } \\
\text { information is prepared }\end{array}$ & 0.598 \\
\hline & $\begin{array}{c}\text { Income statement x Place where financial } \\
\text { information is prepared }\end{array}$ & 0.764 \\
\hline & $\begin{array}{l}\text { Statement of change in equity x Place where } \\
\text { financial information is prepared }\end{array}$ & 0.612 \\
\hline & $\begin{array}{l}\text { Statement of cash flows x Place where financial } \\
\text { information is prepared information is prepared }\end{array}$ & 0.117 \\
\hline & $\begin{array}{l}\text { Disclosures x Place where financial information } \\
\text { is prepared }\end{array}$ & 0.230 \\
\hline
\end{tabular}

These results are consistent with those presented by Bezerra (2012) and Santos (2014), they concluded that it was not possible to find statistical evidence to affirm the existence of an association between the importance given to financial information and the site where it is prepared. By Bezerra (2012) most of the financial information provided by the accounting does not have any association with the place where it is prepared. However, these results aren't in line with those presented by Nunes and Serrasqueiro (2004), who concluded that there is a positive association between the place and the importance given to financial information because business owners/managers tend to give greater importance to the financial information when it is prepared in the company's infrastructure (inside the company). In this respect also Santos (2014) came to argue that the financial information is prepared in the company's infrastructure tends to respond better to the needs of its users, including administrators/managers, which Bezerra (2012) reinforces, saying that when companies have a professional to prepare the financial information in the company's infrastructure tend to better understand its importance and usefulness to the decision-making process. As supported by Breen, Sciulli and Calvert (2004), stating that external information repair can signal the company's internal capacity, sophistication and expertise. Companies that prepare the information internally gain more knowledge about their content and are more comfortable and confident in their use (Smallbone, North \& Leigh, 1993). Nunes and Serrasqueiro (2004) argue that when the financial information is prepared outside the company's aims to respond to tax compliance.

The balance between cost and benefit comes usually presented as a constraint to the preparation and disclosure of timely and relevant financial information. The resources that companies tend to make available for the preparation of information varies according to the importance administrators/managers recognize to them, which does not cease to be associated with the need to balance the costs incurred with the preparation of the expected return. In this regard, it was placed " $\mathrm{RH}_{2}$ : There is an association between the importance given to financial 
information and the cost that the Portuguese CF have with their preparation" and in order to validate it was applied the Phi test. The results obtained for each of the five financial statements present a $\mathrm{p}$ value higher than the significance level 5\% (Table 9). Accordingly, there is not enough statistical evidence to affirm the association between the importance given to financial information and the cost that the $\mathrm{CF}$ have with their preparation, so it is not possible to validate the $\mathrm{RH}_{2}$.

Table 9

Phi test on $\mathrm{RH}_{2}$.

\begin{tabular}{lccc}
\hline \multicolumn{1}{c}{ Research hypotheses } & Variables & Test Value & p-value \\
\hline $\mathbf{R H}_{2}$ : There is an association between the & $\begin{array}{c}\text { Balance sheet x Cost associated with the } \\
\text { preparation of financial information }\end{array}$ & 0.171 & 0.168 \\
$\begin{array}{l}\text { importance given to financial information } \\
\text { and the cost that the Portuguese CF have } \\
\text { with their preparation. }\end{array}$ & $\begin{array}{c}\text { Income statement x Cost associated with the } \\
\text { preparation of financial information }\end{array}$ & 0.241 & 0.052 \\
\cline { 2 - 4 } & $\begin{array}{l}\text { Statement of change in equity x Cost associated } \\
\text { with the preparation of financial information }\end{array}$ & 0.097 & 0.443 \\
\hline $\begin{array}{l}\text { Statement of cash flows x Cost associated with } \\
\text { the preparation of financial information }\end{array}$ & -0.015 & 0.907 \\
\hline $\begin{array}{c}\text { Disclosures x Cost associated with the preparation } \\
\text { of financial information }\end{array}$ & $\begin{array}{c}0.197 \\
0\end{array}$ & 0.148 \\
\hline
\end{tabular}

These results are not consistent with those presented by Ismail and Chandler (2004), cited by Santos (2013), who concluded that companies tend to only produce financial information that is legally obliged, this fact being closely associated with competitiveness and cost that companies have to support with their preparation.

An additional concern of this study has to do with the level of knowledge that administrators/ managers have about the financial information is prepared and the degree or level of use in the decision-making process. For the analysis, it was considered the " $\mathrm{RH}_{3}$ : There is an association between the knowledge of the administrators/managers about financial information prepared by the company and its respective use in the decision making process" and to validate it was used the Fisher test. The results (Table 10) have shown no sufficient statistical evidence to affirm the association between the knowledge of the administrators/managers about the financial information that is prepared by the company and its use in the decision-making process. Thus, it is not possible to corroborate $\mathrm{RH}_{3}$.

Table 10

Fisher test on $\mathrm{RH}_{3}$.

\begin{tabular}{|c|c|c|}
\hline Research hypotheses & Variables & p-value \\
\hline $\begin{array}{l}\mathbf{R H}_{3} \text { : There is an association between the } \\
\text { knowledge of the administrators/mana- } \\
\text { gers about financial information prepared } \\
\text { by the company and its respective use in } \\
\text { the decision making process }\end{array}$ & $\begin{array}{l}\text { Knowledge of the administrators/managers about } \\
\text { financial information prepared by the company } x \\
\text { Using of the financial information in the } \\
\text { decision-making process }\end{array}$ & 0.357 \\
\hline
\end{tabular}


This will result in a way to meet the theory, which has been defending, although with vague or inconclusive results, the administrators/managers have little knowledge about accounting and its potential benefits or to support the decision-making process (Laureano, 2006; Garcia-Perzde-Lema \& Durendéz, 2006; Halabi et al., 2010; Carraher \& Auken, 2013; Santos, 2014) and the administrators/managers tend to use the financial information to respond to tax obligations (Laureano, 2006; Pires \& Rodrigues, 2011; Pires et al., 2015; Rodrigues et al., 2014), although there are already some administrators/managers with a sense of the importance that financial information has (Laureano, 2006). The little knowledge the administrators/managers tend to present does not fail to justify the fact that they do not value it, and therefore, do not seeking or to use them to support the decision-making process (Stroeher \& Freitas, 2008), basing itself generally on intuition (Bezerra, 2012; Pires \& Rodrigues, 2011; Pires et al., 2015; Rodrigues et al., 2014) and in experience (Bezerra, 2012).

The performed literature review also allowed to verify that one of the big

challenges which exist for $\mathrm{CF}$ throughout their life cycle are those resulting from inadequate or deficient capital structure. In this regard, and due to the fact that the CF are associated with a high mortality rate (Filho et al., 2010; Silva et al., 1999), it was considered appropriate to examine whether there is any relationship between the capital structure and the frequency with which these companies use the financial information, or check if those who use the financial information has a higher financial autonomy (equity of $50 \%$ or higher). For the analysis it was considered the "RH. There is a relationship between the use of financial information and capital structure of the company" and to validate it resorted to the application of the Spearman correlation coefficient test. The results show that the probative of p-value obtained in the relationship between the use of the financial information and capital structure (equity and liabilities) is 0.807 , so it is not possible to validate the $\mathrm{RH}_{4}$. The results do not confirm the conclusions of Hanlon and Saunders (2007), and Neeley and Auken (2010), for whom the level of training influences the level of use that is given to the financial information because the greater the probability of a greater understanding of the informational content.

In turn, and to try to realize if the $\mathrm{CF}$ who are in financial equilibrium are those most important to recognize the financial information or, on the contrary, are the CF who are in financial disequilibrium and financial difficulties that most recognize the importance of financial information found to be relevant to analyse whether there is any relationship between the financial autonomy of the $\mathrm{CF}$ and the importance that they assign to the financial information and therefore was considered to " $\mathrm{RH}_{5}$ : There is a relationship between financial autonomy and the importance given to financial information". The results obtained in the relationship between financial autonomy (equity equal or higher than 50\%) and the importance given to the financial information, using the Spearman correlation coefficient test is 0.772 , which it means that not exist sufficient statistical evidence to assert, for a 5\% significance level, that the financial autonomy and the importance given to the financial information are correlated, therefore not corroborating the $\mathrm{RH}_{5}$. These results are not in line with those presented by Neeley and Auken (2010), for whom the level of utility and importance that tends to be attached to financial information grows with the investment.

The available literature shows also that one of the lines of research that have been followed in this respect has to do with the study of the existence of any relationship between the academic education of managers or members of the board of directors and the importance of these assigned financial information. The results available for now are insufficient and 
inconclusive (Nunes \& Sarrasqueiro, 2004; Bezerra, 2012; Santos, 2014). So it was considered the "RH $\mathrm{H}_{6}$ :There is an association between academic education of managers or members of the board and the importance given to financial information" and to validate proceeded to the application of the Phi test. The results (Table 11) reveal no sufficient statistical evidence to say that there is an association between academic education of managers/members of the board of directors and the importance given to the financial information, not confirming RH6. This result is not in line with presented by Nunes and Sarrasqueiro (2004). That point to the existence of a relationship between the level of academic education and the importance given to the financial information, or with those obtained by Bezerra (2012) and Santos (2014), they concluded that not be possible to establish an association between the importance given to the financial information and the level of education. In this respect, it should be noted that the results presented by Halabi et al. (2010) show that homeowners aren't prepared to interpret the contents of financial statements and therefore don't use them when making decisions, or do not feel truly able to interpret their content (Carraher \& Auken, 2013). As we have already noted, the size of the company, the educational level of its owners and the frequency with which the financial information is prepared can be a good indicator of the use and importance attributed to it. Companies that prepare information less frequently are less sophisticated and have lower needs (McMahon \& Stanger, 1995; Cassar, 2009), owners with higher educational attainment have a greater understanding of content (Hanlon \& Saunders, 2007; Neeley \& Auken, 2010 ), in addition to the owners gaining the experience and education necessary to manage the company as it grows (Neeley \& Auken, 2010).

Table 11

Phi test on $\mathrm{RH}_{6}$.

\begin{tabular}{|c|c|c|}
\hline Research hypotheses & Variables & p-value \\
\hline $\begin{array}{l}\mathbf{R H}_{3} \text { : There is an association between the } \\
\text { knowledge of the administrators/mana- } \\
\text { gers about financial information prepared } \\
\text { by the company and its respective use in } \\
\text { the decision making process }\end{array}$ & $\begin{array}{c}\text { Knowledge of the administrators/managers about } \\
\text { financial information prepared by the company } x \\
\text { Using of the financial information in the } \\
\text { decision-making process }\end{array}$ & 0.357 \\
\hline
\end{tabular}

Shaped final summary it should be recalled, in Table 12 below, the HR put in this study as well as a summary of results for each of them. Their analysis shows that any of the six put RH has been validated, so it was not possible to obtain conclusive results for any of them.

Table 12

Summary table of the results obtained for RH.

\begin{tabular}{ll}
\hline Research hypotheses & Validation of hypotheses \\
\hline $\mathbf{R H}_{\mathbf{1}}$ : There is an association between the importance given to financial & Not been validated \\
information and the place where it is prepared. & Not been validated \\
$\overline{\mathbf{R H}}_{2}:$ There is an association between the importance given to financial infor- \\
mation and the cost that the Portuguese CF have with their preparation. & Not been validated \\
$\mathbf{R H}_{3}:$ There is an association between the knowledge of the administrators/ \\
$\begin{array}{l}\text { managers about financial information prepared by the company and its } \\
\text { respective use in the decision making process. }\end{array}$
\end{tabular}




\begin{tabular}{|c|c|}
\hline $\begin{array}{l}\mathbf{R H}_{4} \text { : There is a relationship between the use of financial information and } \\
\text { capital structure of the company. }\end{array}$ & Not been validated \\
\hline $\begin{array}{l}\text { RH: } \text { : There is a relationship between financial autonomy and the importance } \\
\text { given to financial information. }\end{array}$ & Not been validated \\
\hline $\begin{array}{l}\mathbf{R H}_{6}: \text { There is an association between academic education of managers or } \\
\text { members of the board and the importance given to financial information. }\end{array}$ & Not been validated \\
\hline
\end{tabular}

\section{Conclusions, limitations and future research lines}

In fulfilling its mission, financial information plays, or is expected to be, an important role in supporting the decision-making process. However, the studies on this recognition and level of utility in the field of FC, especially small entities, are scarce and not conclusive, so the available evidence in this respect is low. In fact, it was precisely here that we found motivation to carry out this work, whose main objective is to assess the level of importance attributed by these companies to financial information in the decision-making process. In fact, in Portugal, like the most countries of Europe, the number of FC is high and most of them are small.

However, despite this, given the global environment that we live, companies are more exposed and pressed and have permanent needs to adapt to the constant changes that emerge from the surrounding. The CF not only go next to that reality as given their particularities tend to face unique situations. In fact, these companies have been characterised by a high mortality rate, with few who make it beyond the third generation. One way of CF combat this situation goes through effecting changes to various levels, including the need for the management to become more professional and the decision-making process be supported and justified. The use of information, and this particularly timely and quality financial, should be taken as an imperative because there is now a more or less general agreement that the financial information constitutes a differentiator of great importance. This study was developed in this area, specifically in order to investigate the role and importance that is given to the financial information in the decision-making process in CF. To give response were considered six $\mathrm{HR}$ and the results showed that there is insufficient statistical evidence to say that there is an association between (i) the importance given to the financial information and the space where it is prepared; (ii) the importance given to the financial information and the cost that the CF have with their preparation; (Iii) the knowledge of the administrators/managers regarding the financial information prepared by the company and respective use in the decision making process; (Iv) the use of the financial information and capital structure; (V) the financial autonomy and the importance given to financial information; and (vi) the academic education of managers or members of the board of directors and the importance given to financial information.

Has not been also possible to identify, as it was the purpose of this study, a pattern of behavior in relation to the financial information prepared by these companies based on the accounting standards adopted, the business sector and the importance assigned to it depending on the size of the companies.

In addition, and within the different elements that form the basic set of financial statements, it was found that the CF recognize much importance to the balance sheet, income statement and disclosures and moderate importance to the financial information contained in the statement of changes in equity and statement of cash flows. Thus, the financial statements that receive a higher level of recognition and importance for these companies are those that form the basic 
core of the financial statements to prepare as mandatory for any company, regardless of the accounting standards to be applied.

Finally, and with regard to the purpose for which the financial information is used, it was found that the $\mathrm{CF}$ use often information in order to evaluate the financial impacts, to take investment decisions to support the current management and to comply with tax obligations, fundamentally this latter. What is in a way in accordance with the way their administrators/ managers tend to look at her, first as a necessary tool to meet tax requirements and additionally as a support to the decision-making process. In this way, it appears that the main use of the financial information is still to comply with tax obligations.

This study is not, however, and similarly to what happens with respect to any research, free from criticism and constraints, including those resulting from the scarcity of available sources of information on this subject, the lack of a single definition of CF reasonably accepted and able to allow us establish a comparison of results obtained in several researches. And the difficulties to obtain the cooperation of these companies for the study. In this particular, a lot of resistance was found to collaborate on research and some reluctance to provide access to information, with consequent effects on the sample size and the questionnaire responses.

Naturally, some of these limitations can be minimized or even eliminated in future researches by that as future research lines is suggested: an analysis of the mode of operation of reward systems administrators/managers in these companies and their respective penalizations; which their corporate social responsibility; which image they have and what they would like; and what the contribution or the role of accounting in that framework.

\section{References}

Abatti, G. (2004). Avaliação da informação contábil como instrumento da gestão das micro e pequenas empresas, Florianópolis, Universidade Federal de Santa Catarina.

Albuquerque, F., Quirós, J. T., \& Justino, R. (2017). Are the cultural Accounting values a relevant issue for the SME's financing options?. Contaduría y Administración, 62, 279298.

Albuquerque, F., Quirós, J., \& Justino, M. (2013). A utilidade da informação financeira: Estudo empírico sob perspetiva dos preparadores da informação financeira em Portugal, Lisboa, XIV Congresso Internacional de Contabilidade e Auditoria.

Allen, F., \& Gale, D. (2000). Comparing financial systems. Cambridge: MIT Pess.

Almazán, D. A., Tovar, Y. S., \& Quintero, J. M. M. (2017). Influence of information systems on organizational results. Contaduria y Administración, 62, 321-338.

Almeida, A. (2010). Profissionalização em empresas familiares: os desafios da implementação de mecanismos de governança corporativa numa empresa do setor de transportes, Belo Horizonte, Universidade FuMEC/FACE.

Almeida, R. (2012). SNC Legislação, ATF - Edições Técnicas.

Alves, E. (2005). O sistema de informação contábil como instrumento de gestão no terceiro setor, Florianópolis, Universidade Federal de Santa Catarina.

Alves, F., \& Mendonça, C. (2013). Empresa familiar: Um negócio que se adapta ao século 21. Brasil, PwC.

Anderson, R. C., Mansi, S. A., \& Reeb, D. (2003). Funding family ownership and the agency cost debt. Journal of Financial Economics, 68, 263-285.

Andrade, D., Lima, J., Antonialli, L., \& Filho, G. (2013). Estudo dos fatores que determinam a formação do capital social familiar em empresas familiares na região sul de Minas Gerais. Revista de Administração, 48 (3), $426-439$.

APEF (2015). A Associação das Empresas Familiares. Retrieved August 7, 2015, from Empresas Familiares: http:// www.empresasfamiliares.pt/index 
Bezerra, D. (2012). Um estudo sobre a percepção de gestores de médias empresas da região metropolitana de Recife sobre a utilização e importância das informações contábeis no processo de tomada de decisão, Recife, Universidade Federal de Pernambuco.

Bird, B., Welsch, H., Astrachan, J., \& Pistrui, D. (2002). Family Business Research: The Evolution of an Academic Field. Family Business Review, XV(4), 337-350.

Borba, J., Martendal, T., \& Murcia, F. (2006). Analisando a utilização da contabilidade nas empresas familiares de pequeno porte de Santa Catarina: um estudo múltiplo de casos. Revista Catarinense da Ciência Contábil, 5(14), 9-22.

Borges, A., Rodrigues, A., \& Rodrigues, R. (2010). Elementos de Contabilidade Geral, 25ª ed., Áreas Editora.

Borges, L., Silva, M., \& Junior, V. (2013). Modelos de gestão utilizados pela empresa familiar: Madeireira Piranguinhense situada no Sul de Minas Gerais, Brasil, Encontro Científico Sul Mineiro de Administração, Contabilidade e Economia.

Bottino-Antonaccio, C. (2007). Empresas Familiares: uma compreensão sistêmica, Rio de Janeiro, Pontifícia Universidade Católica do Rio de Janeiro.

Brêtas, E., Soares, E., \& Brandão, R. (2011). A Perspectiva das Empresas familiares no Processo de Transição para Seus Sucessores na Cidade de Lajinha/mg, VIII Simpósio de Excelência em Gestão e Tecnologia. Retrieved March 20, 2015, from http://www.aedb.br/seget/arquivos/artigos11/60214763.pdf.

Carraher, S., \& Auken, H. V. (2013). The use of financial statements for decision making by small firms. Journal of Small Business \& Entrepreneurship, 26 (3), 323-336.

Cassar, G. (2009). Financial Statement and Projection Preparation in Start-Up Ventures. The Accounting Review, 84, 27-51.

Centurion, J., \& Viana, J. (2007). Empresa familiar, suas vantagens, desvantagens e desafios: o caso da empresa Recuperadora Bras Soldas Ltda, Brasil. Retrieved March 20, 2015, from http://www.aedb.br/seget/arquivos/artigos07/1162_1162_gestao\%20de\%20empresas\%20familiares.pdf

Coelho, A. (2002). Aspectos críticos numa empresa familiar - Estudo de um caso. Gestin, 1, 51-64.

Correia, T. (2003). Determinantes da estrutura de capital das empresas familiares portuguesas, Faro, Universidade do Algarve.

Dantas, E. (2013). A importância da pesquisa para a tomada de decisões. Retrieved April 3, 2015, from Biblioteca online de ciências da comunicação: http://www.bocc.ubi.pt/pag/dantas-edmundo-2013-importancia-pesquisa-tomada-decisoes.pdf

Dechow, P., Sloan, R., \& Sweeney, A. (1995). Detecting Earnings Managements. Accounting Review, 70(2), $193-225$.

Empresas \& Negócios (2014). Empresas familiares rondam 70\% do total de empresas. Empresas Familiares. Retrieved August 27, 2015, from http://foreigners.textovirtual.com/empresas-familiares/62/129294/empresas-e-negocios-25-mar.pdf

Empresas Familiares (2015). Entrevista com Miguel Ángel Gallo, especialista em empresas familiares, Jornal de Notícias. Retrieved August 16, 2015, from http://empresasfamiliares.jn.pt/2015/07/09/entrevista-com-miguel-angel-gallo-especialista-em-empresas-familiares/\#prettyPhoto.

Faccio, M., \& Lang, L. H. P. (2002). The ultimate ownership of western European Corporations. Journal of Financial Economics, 65 (3), 365-395.

Fernandes, A., \& Ussman, A. (2012). Capacidade de aprendizagem das empresas familiares, Vila Real, XXII ${ }^{\mathrm{a}}$ Jornadas Luso-Espanholas de Gestão Científica.

Ferreira, A. (2008). A divulgação de informação sobre capital intelectual em Portugal, Porto, Universidade do Porto.

Filho, O., Nascimento, J., Borges, G., Soares, K., Moraes, A., \& Teixeira, E. (2010). Gestão Financeira em Micro Empresas Familiares: um Estudo na Indústria Moveleira de Santa Cruz de Minas - MG, VII Simpósio de Excelência em Gestão e Tecnologia. Retrieved March 20, 2015, from http://www.aedb.br/seget/arquivos/artigos10/522_522_Artigo_Gestao\%20Financeira_Final.pdf

Fonseca, A. (2014). A Utilidade da Demonstração de Fluxos de Caixa na Óptica dos Técnicos Oficiais de Contas, Porto, Instituto de Contabilidade e Administração do Porto.

Freitas, E., \& Barth, M. (2011), Profissionalização da gestão nas empresas familiares: estagnar ou inovar?. Revista Brasileira de Gestão e Desenvolvimento Regional, 7(3), 158-185. 
Gallo, M., \& Ribeiro, V. (1996), A gestão das Empresa Familiares, Lisboa, Cadernos Iberconsult.

Garbeti, A., Terrin, A., Bigoni, M., \& Bueno, M. (2008), Empresa familiar: competências e perspectivas, Presidente Prudente, Faculdade de Ciências Econômicas e Administrativas de Presidente Prudente.

Garcia-Perez-de-Lema, D., \& Duréndez, A. (2006). Managerial behavior of small and medium-sized family business: an empirical study. International Journal of Entrepreneurial Behavior \& Research, 13 (3), 151-172.

Gomes, R. (2005), Reorganização empresarial - a empresa familiar (um modelo), Porto, Faculdade de Direito da Universidade do Porto.

Halabi, A., R., Barrett, R. \& Dyt, R. (2010). Understanding Financial Information Used to Assess Small Firm Performance: An Australian Qualitative Study. Qualitative Research in Accounting \& Management 7 (2), 163-179.

Hanlon, D., \& Saunders, C. (2007). Marshaling Resources to Form Small New Ventures: Toward a More Holistic Understanding of Entrepreneurial Support. Entrepreneurship Theory and Practice, 31 (4), 619-641.

Hill, M., \& Hill, A. (2002). Investigação por questionário, Edições Sílabo.

INE (2014). Empresas em Portugal 2012, Instituto Nacional de Estatística, 1-61.

INE (2015). Empresas em Portugal 2013, Instituto Nacional de Estatística, 1-56.

Laureano, A. (2006). A importância da contabilidade como meio de informação no processo decisório das micro e pequenas empresas, Florianópolis, Universidade Federal de Santa Catarina.

Leal, J. (2011). Empresas Familiares - reflexão sobre o seu governo e sucessão. Católica Lisbon School of Business and Economics, Lisboa, Portugal.

Leone, N. (1992). A sucessão em pequena e média empresa comercial na região de João Pessoa. Revista de Administração, 27(3), 84-91.

Lethbridge, E. (1997). Tendências da Empresa Familiar no Mundo. Revista do BNDES, 7, 185200.

Lima, W. (2000). A importância da contabilidade na economia das empresas. Economia \& Pesquisa, 2(2), 79-93.

Lopes, J. (2014). Gestão de Pequenas e Médias Empresas: Importância da Informação Financeira na Tomada de Decisão. Estudo de Caso: PME's na Cidade da Praia, Cabo Verde, Universidade Jean Piaget de Cabo Verde.

Matos, A., Sêrro, S., \& Correia, T. (2007). A estrutura de propriedade como determinante da estrutura de capital - aplicação prática nas empresas familiares portuguesas. Dos Algarves, 16, 56-62.

McMahon, R., \& Stanger, A. (1995). Understanding the Small Enterprise Financial Objective Function. Entrepreneurship: Theory and Practice, 19 (4), 21-40.

Meek, G., \& Thomas, W. (2004). A review of markets-based international accounting research. Journal of International Accounting Research, 3 (1), 21-24.

Milanés, P. M., Lozano, I. A., \& Quirós, J. T. (2011). Accounting standards for small and medium-sized entities: evidence from Spain. Contaduria y Administración, 232, 29-55.

Nascimento, A., Kreisig, D., Springer, F., \& Petry, L. (2005). Um estudo sobre o modelo de gestão das empresas familiares, Florianópolis, IX Congresso Internacional de Custos.

Nascimento, A., Petry, L., Kreisig, D., \& Springer, F. (2006). Um Estudo sobre o Modelo de Gestão e o Processo Sucessório em Empresas Familiares, Salvador, $30^{\circ}$ Encontro da ANPAD.

Neeley, L., \& Auken, H. (2010). Differences Between Female and Male Entrepreneurs' Use of Bootstrap Financing. Journal of Developmental Entrepreneurship, 15(1), 19-34.

Neves, J. (2001). A sucessão na empresa familiar: a estrutura de governo e o controlo do capital, Açores, Conferência de Finanças da Universidade dos Açores.

Nogueira, L., \& Machado, H. (2005). A inserção da empresa familiar no contexto regional paranaense: o caso do restaurante familiar. Caderno de Administração, 13(2), 72-81.

Nunes, L., \& Serrasqueiro, Z. (2004). A informação contabilística nas decisões financeiras das pequenas empresas. Revista Contabilidade \& Finanças, 36, 87-96.

Oliveira, A. (1997). Contabilidade Geral e Financeira, $3^{\mathrm{a}}$ ed., Lisboa, Rei dos Livros.

Pamplona, E., Magro, C., \& Silva, T. (2015). A estrutura de capital e o desempenho econômico de empresas familiares do Brasil e de Portugal, Curitiba, IX Congresso Anpcont.

Passos, Q. (2010). A importância da Contabilidade no Processo de Tomada de Decisão nas Empresas. Retrieved April 5, 2015, from LUME: http://www.lume.ufrgs.br/bitstream/handle/10183/25741/000751647.pdf?sequence=1

Paulo, D. (2009). Empresas familiares em Portugal: “sucessão competente”, Lisboa, Universidade Técnica de Lisboa. 
Petry, L., \& Nascimento, A. (2009). Um estudo sobre o modelo de gestão e o processo sucessório em empresas familiares. Revista Contabilidade \& Finanças, 20(49), 109-125.

Pires, A., \& Rodrigues, F. (2011). As características do tecido empresarial determinam necessidades específicas e definem um utilizador padrão para a informação financeira: evidência empírica, Córdoba, XXI Jornadas Hispano-Lusas de Gestão Científica.

Pires, A., Rodrigues, F., \& Lopes, M. (2015). Os Impostos Diferidos no Balanço: Estudo de caso, Ourense, XXV Jornadas Hispano-Lusas de Gestão Científica.

Radebaugh, L., \& Gray, S. (1993). International accounting and multinational enterprises, New York, John Wiley \& Sons.

Rodrigues, F., Pires, A., \& Pereira, H. (2014). A definição das políticas contabilísticas e a sua relação com as principais forças da envolve: uma interpretação e alguma evidência sobre a influência que é exercida pela fiscalidade, Leiria, XXIV Jornadas Hispano-Lusas de Gestão Científica.

Rodrigues, J. (2011). Sistema de Normalização Contabilística Explicado, Porto Editora.

Santos, A. (2012). A importância da contabilidade na administração da micro e pequena empresa. Revista Conteúdo, 2(1), 38-43.

Santos, M. (2014). A relevância e utilidade das demonstrações financeiras - a perceção dos gestores das PME, Lisboa, Instituto Politécnico de Lisboa.

Santos, S. (2013). A divulgação de informação financeira no relato intercalar: uma análise às entidades cotadas no PSI geral, Lisboa, Instituto Politécnico de Lisboa.

Scholes, M., Wilson, G., \& Wolfson, M. (1990). Tax planning, regulatory capital planning and financial reporting strategy for commercial banks. Review of Financial Studies, 2, 625650.

Sena, D., Santos, E., \& Trzaskos, J. (2013). Gerenciamento de custos em empresas familiares de pequeno e médio porte: desafios e dificuldades. Revista das Faculdades Santa Cruz, 9(1), 5-16.

Shields, J. (2010). Small Business Use of Management Accounting Reports. Small Business Institute Annual Conference, St Petersburg, Florida.

Sian, S., \& Roberts, C. (2009). UK Small Owner-Managed Businesses: Accounting and Financial Reporting Needs. Journal of Small Business and Enterprise Development, 16(2), 289-305.

Silva, J., Fischer, T., \& Davel, E. (1999). Organizações familiares e tipologias de análise: o caso da organização Odebrecht, Brasil, Encontro ANPAD.

Silva, M. (2010). Utilidade da informação contábil para tomada de decisões: Um estudo sobre a percepção dos gestores de micro e pequenas empresas da Grande João Pessoa, João Pessoa - PB, Programa Multi-Institucional e Inter-Regional de Pós-Graduação em Ciências Contábeis da UnB/UFPB/UFRN.

Smallbone, D., North, D., \& Leigh, R. (1993). The Use of External Assistance by Mature SMEs in the UK: Some Policy Implications. Entrepreneurship and Regional Development, 5(3), 279-295.

Stroeher, A., \& Freitas, H. (2008). O uso das informações contábeis na tomada de decisão em pequenas empresas. Revista de Administração, 1(1), 1-25.

Tua, J. (1998). El derecho contable: Una realidad de nuestris dias, Coimbra, VII Jornadas de Contabilidade e Auditoria. Ussman, A. (2004). Empresas Familiares, Lisboa, Edições Sílabo.

Villax, P. (s.d.). Associação Portuguesas das Empresas Familiares. Retrieved January 25, 2015, from APEF: http:// www.empresasfamiliares.pt/mensagem-do-presidente

Watts, R., \& Zimmermann, J. (1978). The Demand for and Supply of Accounting Theories: The Market for Excuses. The Accounting Review, 54(2), 273-305. 